\title{
DEMANDS FOR A RADICAL REVIVAL OF THE EUROPEAN INTEGRATION PLAN. DELIBERATIONS IN THE CONTEXT OF PHILOSOPHY, POLITICAL SCIENCE AND JOURNALISM
}

\begin{abstract}
The separation of theory and practice of the European integration created a very dangerous situation for the European Union. The article presents this crisis from the points of view of philosophy, political science and journalism. The "European poison of thought" expressed by a lack of trust of citizens towards the EU institutions perceived as inadequate in addressing the most fundamental problems of the EU citizens, as well as scepticism towards the enlargement of the Union, aversion to financial solidarity with weaker Member States, and disappointment with legal overregulation and money wasting, are just a few out of a long list of problems that make people lose their trust in the European integration. The author also considers the greatest weaknesses of the European Union: preferring interests of those who are present and well-organised on the political arena and the fact that the real majority of EU citizens stays outside the formal democratic structures thus becoming a part of the process of exclusion and fragmentation. The state of affairs in the EU, following according to Karl Jaspers, is called a limit situation, where it possible either to withdraw or rise and exceed restrictions. The author considers hope and radicalism as two forces that power the European political activists; in order to unite them, a new faith, values and hope based on the traditional foundations are needed. This new way of thinking about the EU, the joined-up thinking, is possibly a response to the demand for a radical revival in the EU.
\end{abstract}

\section{Key words}

European integration, Euro-scepticism, limit situation, radical revival 